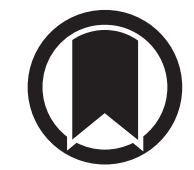

CrossMark

\title{
Ośrodki protonoterapii w Polsce i na świecie
}

\section{Proton beam therapy centers in Poland and worldwide}

\author{
Agata Nowak ${ }^{1}$ \\ ${ }^{1}$ Pracownia Hipertermii, Młodszy Asystent Elektroradiologii
}

\section{Streszczenie}

Ze względu na stały wzrost zachorowań na nowotwory złośliwe, poszukuje się coraz lepszych, bardziej precyzyjnych form leczenia. Obok chirurgii, radioterapii klasycznej czy chemioterapii, terapia protonowa zyskuje coraz większe znaczenie. Obecnie najczęściej stosuje się radioterapię przy użyciu fotonów i elektronów [3,8,9]. Celem leczenia zmian nowotworowych jest ich całkowite usunięcie, przy maksymalnym oszczędzeniu tkanek otaczających, dlatego poszukuje się coraz dokładniejszych metod leczenia [11]. Wykorzystanie protonów zyskuje coraz większe znaczenie, dlatego prowadzone są działania mające na celu wykorzystanie protonów, jako powszechnej formy leczenia zmian nowotworowych. Protony charakteryzują się specyficznym rozkładem głębokościowym. Przy ich użyciu można wysoką dawkę dostarczyć do zadanego punktu - pik Bragga, po czym następuje gwałtowny spadek dawki [4]. Dostarczając punktową, wysoką dawkę do miejsca zadanego można w znaczy sposób oszczędzić tkanki otaczające, a tym samym zmniejszyć ryzyko wystąpienia powikłań, w tym nowotworów wtórnych.

Kliniczne zastosowanie protonów dotyczy przede wszystkim takich miejsc jak mózg czy gałka oczna. Wskazania kliniczne do terapii przy użyciu protonów to dla mózgu: oponiaki (Meningiomas), gruczolaki przysadki (Pituitary adenomas), glejaki (Gliomas), wyściółczaki (Ependymomas), czaszkogradlaki (Craniopharyngiomas), nerwiaki narządu słuchu (Acoustic neuromas) [1].

W przypadku zmian zlokalizowanych w gałce ocznej leczenie protonami wykorzystywane jest w: czerniaku oka (Ocular melanoma), siatkówczaków (Retinoblastomas) [1].

Szczególne zastosowanie dotyczy również protonoterapii w leczeniu zmian nowotworowych w pediatrii. Dodatkowo, tak jak to zostało wspomniane wyżej terapia protonowa pozwala na lepszą ochronę narządów otaczających. Nie jest to jednak terapia pozbawiona wad. Często dużym problemem dla pacjentów są stosowane unieruchomienia, typu maska termoplastyczna, retraktory czy biteblocki. Jej koszt jest wysoki, dlatego też liczba ośrodków jest dość ograniczona.

Liczba ośrodków protonoterapii na świecie ciągle wzrasta. Pierwszym centrum stosującym terapię protonową był Loma Linda University Medical Centre w Kalifornii. Do najważniejszych ośrodków protonoterapii można zaliczyć Paul Scherrer Institute w Szwajcarii, MD Anderson Cancer Center w Houston, Proton Medical Research Center w Tsukuba (PMRC) czy Rinecer Proton Therapy Center (RPTC). W Polsce obecnie znajduje się jeden ośrodek protonoterapii - Centrum Cyklotronowe w Bronowicach.

\section{Agata Nowak}

Pracownia Hipertermii, Młodszy Asystent Elektroradiologii Wielkopolskie Centrum Onkologii, ul. Garbary 15, 61-866 Poznań, Polska e-mail: agata.nowak@wco.pl 


\begin{abstract}
Abstrakt
Proton beam therapy, as a form of treatment of tumors, ensures that a high dose is delivered to the desired volume, while protecting healthy tissue. The continuous development of this method of treatment causes more and more health facilities to offer their patients the treatment of tumours which uses protons. This method has a growing range of applications and it is used primarily to treat such locations as the eyeball or brain. Proton beam therapy is an exceptionally effective treatment of malignancies in children due to the maximum protection of healthy tissues. This paper describes selected proton beam therapy centers in Poland and worldwide. There is one center currently operating in Poland - Cyclotron Center in Bronowice (CCB - IFJ PAN) - which mainly deals with the treatment of lesions located in the eyeball. It should also be mentioned that Poland started the INPRONKO project, which largely contributes to the development of proton beam therapy in our country This work also describes such institutions as the Paul Scherrer Institute where the dynamic beam scanning was used for the first time, the Joint Institute for Nuclear Research (JINR) in Dubna, and the Rinecker Proton Therapy Center in which three-dimensional proton beam is used in treatment. Another health facility, which is presented in this paper, is the MD Anderson Cancer Center which specializes in the treatment of neoplastic conditions using IMPT. Proton Medical Research Center in Tsukuba is a health center where, apart from the eyeball, some other organs, such as the liver, prostate or oesophagus are also irradiated.
\end{abstract}

Stowa kluczowe: protonoterapia, centra protonoterapii

Keywords: proton therapy, proton therapy center

\title{
Ośrodki protonoterapii w Polsce i na świecie.
}

Jedyną funkcjonującą placówką protonoterapii na terenie Polski jest Centrum Cyklotronowe w Bronowicach, w którym wykorzystuje się cyklotron AIC - 144, generujący wiązkę o energii $60 \mathrm{MeV}$, zbudowany przez Instytut Fizyki Jądrowej PAN [2]. W Centrum Cyklotronowym obecnie stosuje się jedynie terapię protonową oka. Terapia jest wykonywana przy współpracy z Kliniką Okulistyki i Onkologii Okulistycznej CM UJ, Szpitala Uniwersyteckiego w Krakowie oraz Centrum Onkologii w Krakowie [2].

Centrum Cyklotronowe Bronowice ulega ciągłej modernizacji, realizowane są projekty rozwoju placówki, poprzez wykorzystanie cyklotronu izochronicznego Proteus C - 235, który przyspiesza cząstki od energii $70 \mathrm{MeV}$ do $235 \mathrm{MeV}$ [2]. Obecnie realizowany jest projekt „Centrum Cyklotronowe Bronowice - stanowisko gantry”, którego celem jest instalacja ramienia obrotowego, które pozwoli na dostarczanie wiązki protonowej w pełnym zakresie kątowym wokół osi izocentrum [2]. Stanowisko zostanie wyposażone w głowicę dedykowaną dla wiązki skanującej. Zastosowanie takiego rozwiązania pozwoli w pełni wykorzystać cechy cyklotronu Proteus C- 235, co doprowadzi do rozwoju zarówno terapeutycznego jak i badawczego. Pozwoliło by to między innymi na rozszerzenie terapii do leczenia zmian centralnego układu nerwowego [2].

Wiązka protonów musi zostać odpowiednio uformowana, co odbywa się w pomieszczeniu terapeutycznym na tzw. „ławie optycznej”. Procedura radioterapii jest wieloetapowa. Pierwszy z etapów realizowany jest w Klinice Okulistyki i Onkologii Okulistycznej w Krakowie, gdzie dokonywana jest dokładna diagnostyka nowotworu, określanie położenia czy wielkości guza [2]. Aby możliwe było odpowiednie pozycjonowanie, przy udziale zestawu RTG, należy wykonać zabieg operacyjny, podczas którego naszywa się znaczniki tantalowe na twardówkę [2]. Rycina 1 przedstawiona poniżej pokazuje klipsy tantalowe stosowane do leczenia terapią protonową.

Następnie pacjent udaje się do Instytutu Fizyki Jądrowej, gdzie zostaje opracowany odpowiedni plan leczenia. Pacjent przed napromienianiem musi zostać odpowiednio wypozycjonowany, następnie fizycy opracowują szczegółowy plan leczenia, przeprowadzają weryfikację planu leczenia a następnie dokonuje się procedury napromieniania.

Kolejnym krokiem w rozwoju protonoterapii w Polsce może stać się Projekt INPRONKO, który realizowany będzie przez konsorcjum 19 instytucji: uniwersytetów i ośrodków onkologicznych z pięciu województw 

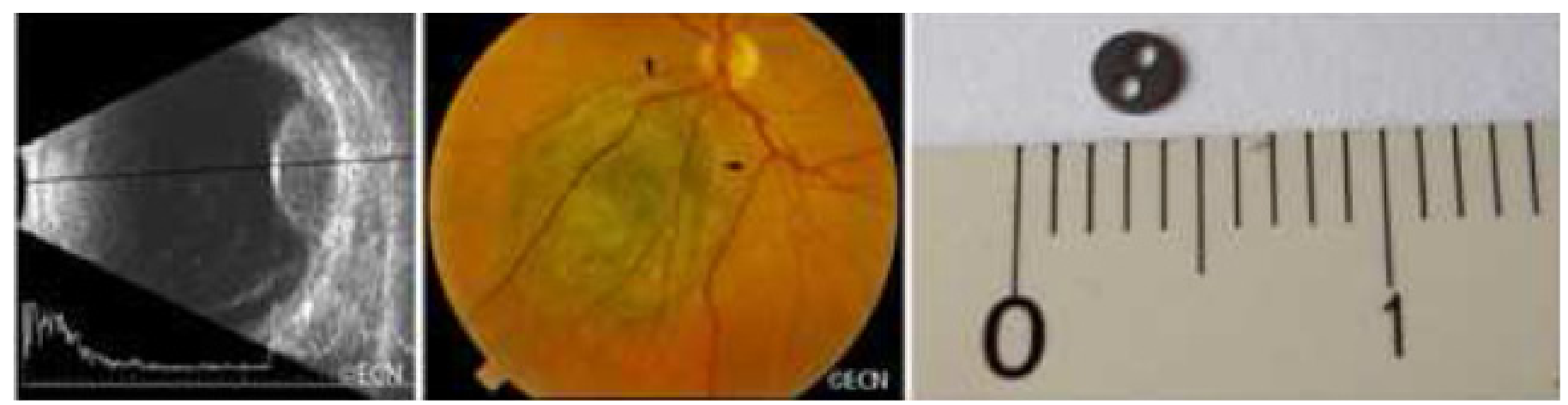

Rycina 1. Klipsy tantalowe [2]

Polski Zachodniej: Dolnośląskie Centrum Onkologii, Wojewódzki Szpital w Zielonej Górze (Lubuski Ośrodek Onkologii), SPZOZ Opolskie Centrum Onkologii im. Prof. T. Koszarowskiego, Wojewódzki Szpital Zespolony w Opolu, Wielkopolskie Centrum Onkologii im. M.Skłodowskiej - Curie - Lider Konsorcjum, Szpital Kliniczny Przemienienia Pańskiego w Poznaniu, Zachodniopomorskie Centrum Onkologii [5]. Nadzór merytoryczny nad projektem sprawuje Rada Naukowa złożona z liderów pakietów oraz przedstawicieli opiniotwórczych środowisk naukowych. Przewodniczącym Rady Naukowym jest prof. dr hab. Jacek Fijuth. Natomiast Koordynatorem projektu jest prof. dr hab. Julian Malicki, dyrektor Wielkopolskiego Centrum Onkologii w Poznaniu i kierownik Katedry i Zakładu Elektroradiologii Uniwersytetu Medycznego w Poznaniu [5]. W ramach projektu przewiduje się m.in. utworzenie centrum i systemu radioterapii protonowej, wdrożenie celowanej profilaktyki i indywidualizację leczenia onkologicznego poprzez integrację interdyscyplinarnych świadczeń medycznych w powiązaniu z badaniami molekularnymi, zwiększenie skuteczności leczenia poprzez poprawę dostępności i integrację świadczeń radioterapii w Polsce Zachodniej.

Pierwszym powstałym w Europie ośrodkiem był Paul Scherrer Institute (PSI) mieszczący się w Szwajcarii. Napromienianie pacjentów dotyczyło początkowo tylko okolic gałki ocznej. Pierwszy pacjent został napromieniony w 1984 roku. Było to zarazem pierwsze na świecie tego typu napromienianie. W 1996 roku zainstalowano w PSI pierwsze gantry do terapii protonowej guzów znajdujących się na większych głębokościach [16]. W Paul Scherrer Institute wykorzystuje się cyklotron COMET, pokazany na ryc. 2, za pomocą którego produkowana jest wiązka elektronów o szerokości od 5 do $7 \mathrm{~mm}$

Obecnie w PSI wykorzystuje się 2 gantry. Jedno z nich przygotowane jest do leczenia zmian zlokalizowanych w narządach charakteryzujących się dużą ruchomością, np. nowotwory płuc. Wiązka prowadzona jest przez układ magnesów, odchylających wiązkę w dwóch kierunkach na różnym poziomie, dzięki czemu wiązka trafia w zadane miejsce. Dodatkowo energia wiązki może ulec zmianie w ułamku sekundy, w związku z tym napromienianie odbywa się w trzech wymiarach. Do 2010 roku ponad 5500 pacjentów z nowotworem gałki ocznej zostało skutecznie wyleczonych w PSI [16].

PSI to pierwszy instytut, w którym wykorzystano dynamiczną wiązkę skanującą i układ magnetyczny do sterowania wiązką (płaszczyzna xy) [16]. Opracowano ją w 1990 roku, co pozwoliło na znaczną poprawę w ochronie tkanek zdrowych

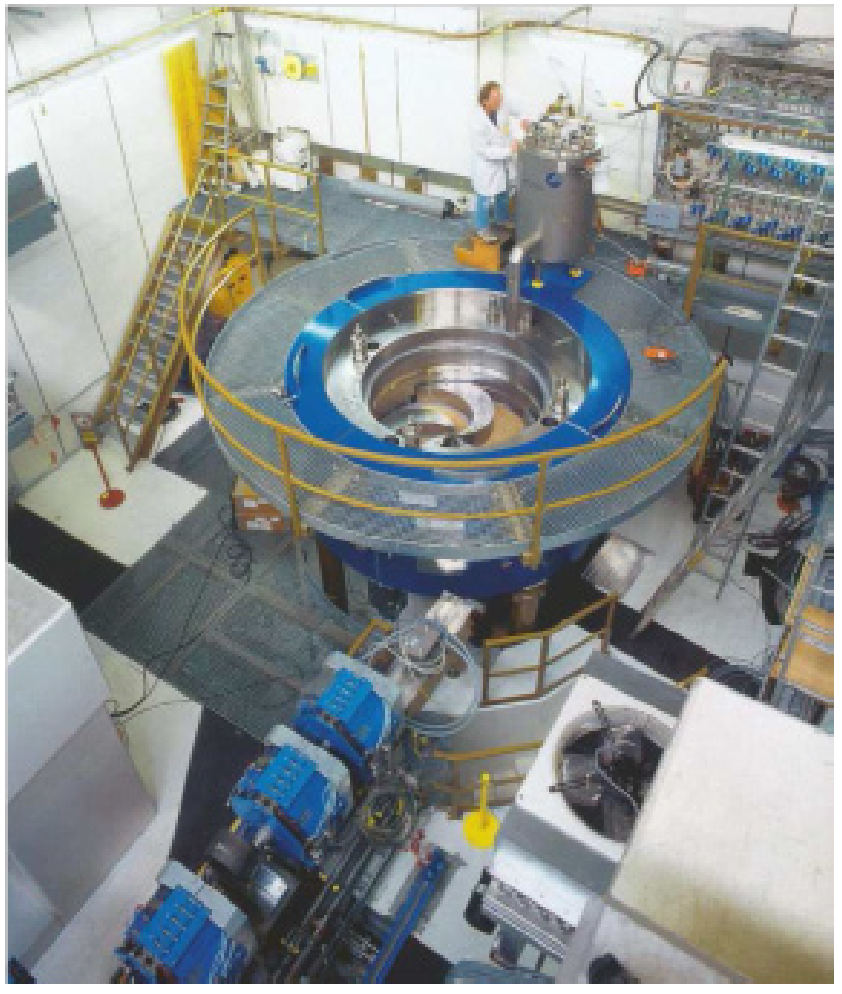

Rycina 2. Cyklotron COMET [16] 


\section{Zjednoczony Instytut Badań Jądrowych} znajdujący się w Dubnej powstał na mocy konwencji podpisanej w 1956 roku w Moskwie przez przedstawicieli jedenastu państw w celu połączenia ich potencjałów naukowych i materialnych, aby badać podstawowe właściwości materii [12]. Obecnie Instytut tworzy 18 państw członkowskich, w tym między innymi Polska [12]. ZIBJ wykorzystuje cyklotron U-400 i U-40oM, reaktor IBR-2 z pulsującą wiązką neutronów, akceleratorem protonów, zwanym „fazotronem”. Za pomocą fazotronu wytwarzana jest wiązka protonów o energii $670 \mathrm{MeV}$. Spowolniona do $175 \mathrm{MeV}$, wykorzystywana jest do leczenia nowotworów, przede wszystkim zlokalizowanych w obrębie czaszki, blisko narządów krytycznych. $\mathrm{W}$ ośrodku tym wykorzystuje się pojedynczy pasywny system rozpraszania. Pole jakie można uzyskać ma wymiary 9,5 na $9,5 \mathrm{~cm} 2[1]$.

W ZIBJ wykorzystuje się trójwymiarową terapię konformalną, a więc bierną modyfikację wiązki [13]. Natomiast system służący do planowania leczenia to OptiRad 3D, który został stworzy w centrum w LomaLinda [7].

W Ameryce znajduje się bardzo dużo placówek

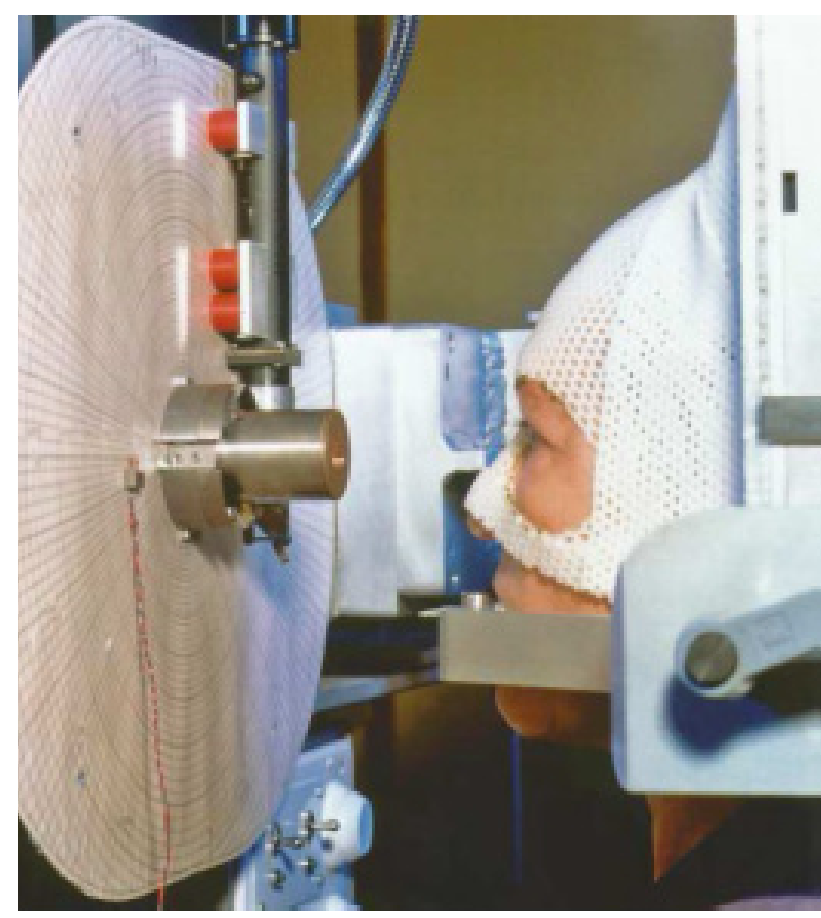

Rycina 3. Procedura napromieniania nowotworów gałki ocznej [16]

radioterapeutycznych, w tym udzielających świadczeń w zakresie protonoterapii. Jest to między innymia MD Anderson Cancer Center w Houston w USA, który powstał w 2006 roku. Wykorzystuje cyklotron o energii do $250 \mathrm{MeV}$, a do grudnia 2012 roku leczono w tym ośrodku prawie 4000 pacjentów [12]. W MD Anderson Cancer Center początkowo stosowano technikę napromieniania - Pencil beam, w leczeniu zmian w miednicy czy mózgu. Obecnie jest to jedyny ośrodek w Ameryce Północnej, który wykorzystuje najbardziej specjalistyczną technikę napromieniania przy pomocy protonów - IMPT (ang. Intensity Modulated Proton Therapy) [1,14]. IMTP pozwala przede wszystkim na leczenie zmian, które charakteryzują się położeniem na różnej głębokości czy skomplikowanym kształtem. Pencil beam zakłada napromienianie jednocześnie całej objętości tarczowej, natomiast IMPT dzieli daną objętość na warstwy. IMPT pozwala na znaczne ograniczenie skutków ubocznych promieniowania [1,6]. W MD Anderson Cancer Center dokonywane jest napromienianie nie tylko gałki ocznej czy mózgu, ale szereg innych umiejscowień nowotworów.

MD Anderson jest zdecydowanie jednym z wiodących centrów protonoterapii na świecie. Rinecer Proton Therapy Center (RPTC), to ośrodek, który znajduje się w Niemczech i powstał w 2009 roku. Jest jednym z pierwszych ośrodków, który zajął się protonoterapią pacjentów, a nie tylko w celach naukowych [19]. Ośrodek ten posiada system zaprojektowany i zoptymalizowany do metody aktywnego skanowania. W RPTC stosuje się wysoce specjalistyczną aparaturę, która pozwala na użycie trójwymiarowej wiązki protonowej z dokładnością +/- 1 milimetr [19].

Sercem aparatury stosowanej w centrum, pozwalającym na tak precyzyjną formę leczenia jest tzw. Nozzle. Jest to element mocowany na końcu drogi protonów, dostarczający wiązkę do pacjenta. Mocuje się go w pobliżu pacjenta, przez co protony mogą być transportowane w próżni, bez rozpraszania. Zawiera 2 pary magnesów, które odchylają wiązkę w dwóch wymiarach od osi gantry w jednym kierunku i równolegle do osi gantry w drugim kierunku [19]. Trzeci wymiar wiązki, realizowany jest poprzez regulację energii wiązki, a więc głębokości jej wnikania.

W 2000 roku w Azji, w Tsukuba powstał Proton Medical Research Center (PMRC), gdzie wykorzystywany jest synchrotron, wytwarzający wiązkę o energii od $70 \mathrm{MeV}$ do $250 \mathrm{MeV}$. Ośrodek dysponuje dwoma gantry, układem stacjonarnym do napromieniania oraz znajdującym się tuż obok pomieszczeń terapeutycznych dużym zakładem diagnostyki obrazowej niezbędnym do przygotowywania planów leczenia [18].

Wiązka pierwotna ma małe rozmiary, a więc aby napromienić zmiany o większych wymiarach należy 
dokonać rozszerzenia wiązki. W PMRC stosuje się podwójne rozpraszanie, gdzie grubości materiałów rozpraszających dobierane są automatycznie [18]. Zastosowane filtry grzebieniowe powodują wzrost lub spadek energii w zależności od objętości guza [10,14]. W Ośrodku w Tsukuba napromieniane są przede wszystkim guzy nowotworowe w takich narządach jak: wątroba, płuca, gruczoł krokowy, przełyk czy mózg [18]. Dokonuje się tu również napromieniania zmian nienowotworowych, np. malformacji tętniczo-żylnych.

\section{Podsumowanie}

Coraz większa liczba ośrodków oferuje leczenie przy pomocy protonoterapii [15]. Udział procentowy poszczególnych kontynentów pokazuje rycina przedstawiona poniżej. Można wnioskować, iż Europa nadal znacząco odbiega pod względem liczny centrów protonoterapii od dominującej Azji.

Dokonując oceny powyższego przeglądu można stwierdzić, że protonoterapia rozwija się coraz prężniej i jej znaczenie w leczeniu zmian nowotworowych wzrasta. Pewnym jest, iż korzyści wynikające $\mathrm{z}$ zastosowania tej metody leczenia w onkologii są ponad koszty i trudności jakie należy ponieść przy realizacji terapii. Oceniając protonoterapię pod względem ilości działających ośrodków, to niewątpliwie jednymi z najbardziej rozwiniętych placówek jest MD Anderson Cancer Center w Houston, Paul Scherrer Institute w Szwajcarii a także mieszczący się w Azji Proton Medical Research Center. Każda z tych placówek dokonuje ciągłego ulepszania aparatury oraz procedury napromieniania. Rozwój protonoterapii w Polsce jest zdecydowanie zbyt wolny w stosunku do pozostałych krajów, co przede wszystkim związane jest w z wysokimi kosztami stworzenia tego typu ośrodków oraz leczenia. Świadomość populacji na temat problematyki onkologicznej jest już na tyle duża, iż wydaje się realnym znaczący rozwój dziedziny

Centra protonoterapii na świecie

Europa azja AfrykaPoludniowa Ameryka

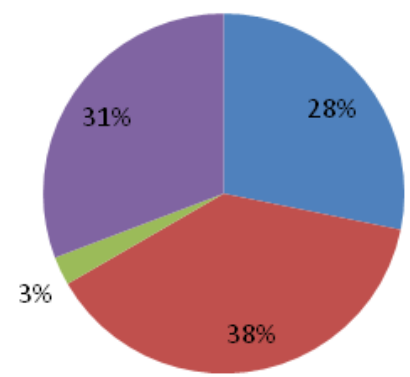

Wykres. Liczba ośrodków protonoterapii na świecie z podziałem na kontynenty.

jaką jest protonoterapia w Polsce. Projekt INPRONKO umożliwi utworzenie wysokospecjalistycznej bazy aparaturowej w zakresie terapii i diagnostyki chorób nowotworowych bezpośrednio w ośrodkach onkologicznych w Poznaniu, Szczecinie, Opolu, Wrocławiu i Zielonej Górze, a więc jest to poważny krok w budowaniu pożądanego poziomu radioterapii w Polsce.

\section{Piśmiennictwo / References}

[1] Breuer H, Smith BJ. Proton therapy and radiosurgery. Berlin: Wydawnictwo Springer; 2000.

[2] Centrum Cyklotronowe Bronowice. Materiał internetowy dostępny pod adresem: http://www.ifj.edu.pl/ccb/.

[3] Dirk De Ruysscher M. Lodge M, Bleddyn J. i In, Charged particles in radiotherapy: A 5-year update of a systematic review,Radiother and Oncol 2012; 103:5-7.

[4] Goitein M. Radiation Oncology : A Physicist's -Eye View. Biol and Med Phys, Biological Engineering 2008.

[5] Projekt INPRONKO. Materiał dostępny na stronie internetowej www.inpronko.eu.

[6] Jędrzejczak D.M. Porównanie obliczonych i zmierzonych rozkładów dawek w wiązce protonowej, modyfikowanej bolusami woskowymi, dla wybranych przypadków klinicznych. Praca magisterska, Uniwersytet Adama Mickiewicza, Poznań, 2011.

[7] Loma Linda University Medical Center. Conditions treated with protons. Materiał internetowy dostępny pod adresem: http://www.protons.com./proton-therapy/conditions-treated/index.html.

[8] Łobodziec W. Dozymetria promieniowania jonizującego w radioterapii. Katawice: Wydawnictwo Uniwersytetu Ślaskiego; 1999.

[9] Ma C-M, Tajima T, Shahine B, Lee MC, Guerrero T, Boyer AL. Laser accelerated proton beams for radiation therapy. Med Phys 2001;28:1236. 
[10] Malicki J. The importance of accurate treatment planning, delivery and dose verification. Rep Pract Oncol Radiother 2012;17(2)63-65.

[11] Marks L.B, Yorke E.D, Jackson A, i In. Use on normal tissue complication probability models in the clinic, Int J Radiat Oncol Biol Phys 2010;76(3):10-19.

[12] MD Anderson Cancer Center. Materiał internetowy dostępny na stronie www.mdanderson.org.

[13] Mumot M. Opracowanie uproszczonej metody obliczeń i pomiarów dawek w radioterapii protonowej 70-250 MeV oraz porównanie otrzymanych rozkładów dawek z rozkładami dla promieniowania dotonowego/elektronowego (4-25 MeV/3-25 MeV), w wybranych przypadkach klinicznych, praca doktorska Uniwersytet Medyczny im. Karola Marcinkowskiego, Poznań 2008.

[14] Mumot M, Mytsin G, Molokanov A, Malicki J. The comparison of doses measured by radiochromic films and semiconductor detector in a $175 \mathrm{MeV}$ proton beam. Phys Med. 2009;25(3): 105-110.

[15] Particle Therapy Co-Operative Group. Particle therapy facilities in operation. Materiał internetowy dostępny pod adresem: http://ptcog.web.psi.ch/ptcentres.html.

[16] Paul Scherrer Institute. Materiał internetowy dostępny pod adrsem: http://www.psi.ch/.

[17] Podgorsak E.B. Radiation Oncology Physics: a handbook for Teachers and Students. International Atomic Energy Agency 2005.

[18] Proton Medical Research Center.Materiał internetowy dostępny pod adresem: http://www.pmrc. tsukuba.ac.jp.

[19] Rinecer Proton Therapy Center. Materiał internetowy dostępny pod adresem: http://www.rptc.de/. 